\title{
AMENDMENTS
}

\section{Publisher Correction: Altered perivascular fibroblast activity precedes ALS disease onset}

Anna Månberg (D), Nathan Skene, Folkert Sanders, Marta Trusohamn (D), Julia Remnestål, Anna Szczepińska, Inci Sevval Aksoylu, Peter Lönnerberg, Lwaki Ebarasi, Stefan Wouters (1), Manuela Lehmann, Jennie Olofsson (D), Inti von Gohren Antequera, Aylin Domaniku (D), Maxim De Schaepdryver (D), Joke De Vocht, Koen Poesen, Mathias Uhlén (10), Jasper Anink, Caroline Mijnsbergen, Hermieneke Vergunst-Bosch, Annemarie Hübers, Ulf Kläppe (10), Elena Rodriguez-Vieitez, Jonathan D. Gilthorpe (D), Eva Hedlund (1D, Robert A. Harris (D), Eleonora Aronica, Philip Van Damme (D), Albert Ludolph, Jan Veldink (10, Caroline Ingre, Peter Nilsson (10) and Sebastian A. Lewandowski (1) Correction to: Nature Medicine https://doi.org/10.1038/s41591-021-01295-9, published online 15 April 2021.

In the version of this article initially published, the label along the right margin of the top row in Fig. $2 \mathrm{~d}\left(S O 1 D^{\mathrm{G} 93 A}\right)$ was incorrect. The correct label is ' $S O D 1^{G 93 A}$ '. The error has been corrected in the HTML and PDF versions of the article.

Published online: 2 June 2021

https://doi.org/10.1038/s41591-021-01414-6

(c) The Author(s), under exclusive licence to Springer Nature America, Inc. 2021

\section{Publisher Correction: Prisons as ecological drivers of fitness-compensated multidrug-resistant Mycobacterium tuberculosis}

Sebastian M. Gygli, Chloé Loiseau, Levan Jugheli, Natia Adamia, Andrej Trauner $\mathbb{D}$, Miriam Reinhard, Amanda Ross (D), Sonia Borrell, Rusudan Aspindzelashvili, Nino Maghradze, Klaus Reither, Christian Beisel Di, Nestani Tukvadze, Zaza Avaliani and Sebastien Gagneux (D)

Correction to: Nature Medicine https://doi.org/10.1038/s41591-021-01358-x, published online 24 May 2021.

In the version of this article initially published, the genus name was spelled incorrectly ('Mycobacteritum') in the title. The correct spelling is 'Mycobacterium'. The error has been corrected in the HTML and PDF versions of the article.

Published online: 1 June 2021

https://doi.org/10.1038/s41591-021-01417-3

(c) The Author(s), under exclusive licence to Springer Nature America, Inc. 2021 